\title{
Low body weight/thinness, overweight and obesity of children and adolescents from a Brazilian region of low economic status
}

Baixo peso corporal/magreza, sobrepeso e obesidade de crianças e adolescentes de uma região brasileira de baixo desenvolvimento econômico

Bajo peso corporal/delgadez, sobrepeso y obesidad de niños y adolescentes de una región brasileña de bajo desarrollo económico

Dartagnan Pinto Guedes ${ }^{1}$, Francisléia Nascimento Almeida², Jaime Tolentino M. Neto ${ }^{3}$, Maria de Fátima de M. Maia ${ }^{3}$, Thatiana Maia Tolentino²

\section{ABSTRACT}

Objective: To assess the prevalence of low body weight/ thinness, overweight and obesity in a representative sample of children and adolescents from a Brazilian region with low economic development.

Methods: A total of 982 girls and 986 boys, aged seven to 17 years old and assisted by Segundo Tempo Program, from Montes Claros, Minas Gerais, Brazil, were included in the study. Low body weight/thinness, overweight and obesity were defined based on body mass cut-off indexes recommended by the International Obesity Task Force. The prevalence of the nutritional status according to sex and age was compared by chi-square test.

Results: In girls, the frequency of low body weight/thinness, overweight and obesity was $4.1,18.4$ and $3.8 \%$, respectively; in boys, these percentages were 6.3, 13.2 and 2.9\%, respectively. The low body weight/thinness for girls raised from $2.7 \%$ (7-10 years old) to $5.5 \%$ (15-17 years old); the body weight excess (overweight and obesity) decreased from 30.1 to $16.2 \%$ for the same age groups. In boys, the corresponding trends were from 3.2 to $9.4 \%$ for low body weight/ thinness, and from 23.4 to $9.2 \%$, for body weight excess.

Conclusions: The data indicate that, even in a region with low economic status, the body weight excess was the main problem associated with nutritional health. The high

Instituição: Universidade Norte do Paraná (Unopar), Londrina, PR, Brasil

${ }^{1}$ Centro de Pesquisa em Ciências da Saúde da Unopar, Londrina, PR, Brasil ${ }^{2}$ Secretaria Municipal de Juventude, Esporte e Lazer de Montes Claros, Montes Claros, MG, Brasil

${ }^{3}$ Universidade Estadual de Montes Claros (Unimontes), Montes Claros, MG, Brasil overweight and obesity prevalence rates indicate the need of public policies for promoting healthy feeding behaviors and physical activity.

Key-words: anthropometry; body mass index; nutritional status; child; adolescent.

\section{RESUMO}

Objetivo: Analisar a prevalência de baixo peso corporal/ magreza, sobrepeso e obesidade em amostra representativa de crianças e adolescentes de uma região brasileira de baixo desenvolvimento econômico.

Métodos: Amostra constituída por 982 moças e 986 rapazes, de sete a 17 anos, assistidos pelo núcleo do Programa Segundo Tempo de Montes Claros, Minas Gerais. Definiram-se baixo peso corporal/magreza, sobrepeso e obesidade pelo índice de massa corpórea, adotando-se os pontos de corte recomendados pela International Obesity Task Force. Compararam-se as prevalências de sexo e idade pelo teste do qui-quadrado.

Resultados: Nas moças, as prevalências de baixo peso corpo$\mathrm{ral} /$ magreza, sobrepeso e obesidade foram de 4,1, 18,4 e 3,8\%, respectivamente; nos rapazes, foram de 6,3, 13,2 e 2,9\%. Nas moças, o índice de baixo peso corporal/magreza aumentou de 2,7 para 5,5\% para as faixas etárias de 7-10 e de 15-17 anos, respectivamente; já o excesso de peso corporal (sobrepeso e
Endereço para correspondência:

Dartagnan Pinto Guedes

Rua Ildefonso Werner, 177 - Condomínio Royal Golf

CEP 86055-545 - Londrina/PR

E-mail: darta@sercomtel.com.br

Fonte financiadora: o primeiro autor é bolsista de Produtividade Científica do Conselho Nacional de Desenvolvimento Científico e Tecnológico (CNPq) Conflito de interesse: nada a declarar

Recebido em: 6/2/2013

Aprovado em: 10/5/2013 
obesidade) diminuiu de 30,1 para $16,2 \%$, respectivamente para essas faixas etárias. Nos rapazes, as tendências correspondentes foram de 3,2 para 9,4\% para o baixo peso corporal/magreza, e de 23,4 para 9,2\% para o excesso de peso corporal.

Conclusões: Os dados apontam que, mesmo em uma região de baixo desenvolvimento econômico, o excesso de peso corporal foi o principal problema associado ao estado nutricional. A elevada prevalência de sobrepeso e obesidade alerta para a necessidade de políticas públicas direcionadas às práticas de alimentação saudável e de atividade física.

Palavras-chave: antropometria; índice de massa corporal; estado nutricional; criança; adolescente.

\section{RESUMEN}

Objetivo: Analizar la prevalencia de bajo peso corporal/ delgadez, sobrepeso y obesidad en una muestra representativa de niños y adolescentes de una región brasileña de bajo desarrollo económico.

Métodos: Muestra constituida por 982 muchachas y 986 muchachos, de siete a 17 años, por el núcleo del Programa Segundo Tiempo de Montes Claros, Minas Gerais. Se definieron bajo peso corporal/delgadez, sobrepeso y obesidad por el índice de masa corporal, adoptándose los puntos de corte recomendados por la International Obesity Task Force. Se compararon las prevalencias de sexo y edad por la prueba de chi-cuadrado.

Resultados: En las muchachas, las prevalencias de bajo peso corporal/delgadez, sobrepeso y obesidad fueron de 4,1, 18,4 y $3,8 \%$, respectivamente; en los muchachos, fueron de $6,3,13,2$ y $2,9 \%$. En las muchachas, el índice de bajo peso corporal/delgadez aumentó de 2,7 para 5,5\% para las franjas de edad de siete a 10 y de 15 a 17 años, respectivamente; el exceso de peso corporal (sobrepeso y obesidad), a su vez, redujeron de 30,1 para $16,2 \%$, respectivamente, para esas franjas de edad. En los muchachos, las tendencias correspondientes fueron de 3,2 para 9,4\% para bajo peso corporal/delgadez, y de 23,4 para 9,2\% para el exceso de peso corporal.

Conclusiones: Los datos señalan que, aunque en una región de bajo desarrollo económico, el exceso de peso corporal fue el principal problema asociado al estado nutricional. Las elevadas prevalencias de sobrepeso y obesidad alertan para la necesidad de políticas públicas dirigidas a las prácticas de alimentación sana y de actividad física.

Palabras clave: antropometría; índice de masa corporal; estado nutricional; niño; adolescente.

\section{Introduction}

Nutrition transition describes the process in which changes are observed over time with regard to dietary and physical activity patterns. Although currently nutritional transition has been reaching the entire population, especially developing societies, this process may be distinguished in terms of moment and intensity of occurrence, according to the epidemiological context being considered. The decrease in the prevalence of low body weight/thinness and the increase in the frequency of overweight and obesity, the so-called double burden of malnutrition ${ }^{(1)}$, are essential characteristics of the nutrition transition process.

In this sense, the association between malnutrition, overweight, obesity, health status and well-being is well documented in the literature. Evidence suggests that malnutrition, at younger ages, affects physical growth and cognitive development, favors the onset of infectious diseases, limits physical capacity ${ }^{(2)}$ and, at early adulthood, increases predisposing risks for many degenerative diseases ${ }^{(3)}$. On the other hand, overweight and obesity are known outcomes related to the development of diabetes, heart diseases, osteoarthritis, some types of cancer, among other chronic diseases ${ }^{(4)}$. Overweight and obese youths tend to have a higher incidence of problems related to self-esteem and self-concept, affecting interpersonal relationships ${ }^{(5)}$.

When observing the nutrition transition process in Latin American countries over the past few decades, specifically in Brazil, a significant change was found in the prevalence of low body weight/thinness, overweight and obesity. A comparison of two representative surveys of the young Brazilian population aged from ten to 19 years — the National Study on Family Expenses (Estudo Nacional de Despesa Familiar, Endef), conducted in 1974-1975(6), and the National Family Budget Survey (Pesquisa Nacional de Orçamentos Familiares, POF), conducted in 2002-2003 $3^{(7)}$ - shows that, over three decades, excess body weight had a more than four-fold increase in boys (3.9 versus $18.0 \%$ ) and a more than two-fold increase in girls (7.5 versus $15.4 \%$ ). Additionally, according to the POF, $2.3 \%$ of Brazilian youngsters were obese. As for low body weight/thinness, the Endef indicated similar prevalence in both genders, corresponding to $4.8 \%$, while the POF reported a significant reduction in boys $(2.8 \%)$ and a similar proportion in girls (4.7\%). Therefore, data from both studies show a trend of reduction in the proportion of Brazilian youths with low body weight/thinness and of alarming increase in the prevalence of overweight and obesity. 
The identification of possible nutritional inadequacies in specific segments of the youth population may subsequently provide useful information for the planning of Public Health intervention programs. Thus, this study assessed nutritional status - with a particular focus on the prevalence of low body weight/thinness, overweight and obesity — in a sample of children and adolescents assisted by the Segundo Tempo Program of the Ministry of Sports in the city of Montes Claros, state of Minas Gerais, Brazil.

\section{Method}

This is a cross-section study involving youngsters of both genders, aged from seven to 17 years and participating in the Segundo Tempo Program. Data were collected between April and May 2011 and the study intervention protocol was approved by the Research Ethics Committee of Universidade Estadual de Montes Claros (Unimontes).

The city of Montes Claros, the setting of the present study, is located in northern Minas Gerais. Taking the Human Development Index (HDI) as a reference, it can be observed that, over the past two decades, the city has shown significant improvement. However, it still has lower HDI values compared to cities with similar population density and located in other Brazilian regions, especially in Southeastern and Southern Brazil. In the 1991-2000 period, the HDI for Montes Claros increased by $10 \%$, going from 0.721 , in 1991 , to 0.783 , in 2000 . The dimension that contributed the most to this increase was education $(0.793$ versus 0.872$)$, followed by income (0.629 versus 0.681$)$ and life expectancy $(0.741$ versus 0.787 ). In this period, the human development gap, i.e., the distance between the city HDI and HDI maximum score (1-HDI), was reduced by 32\%. Mean 2000 HDI for the cities located in Southeastern and Southern Brazil was 0.844 and 0.825 , respectively, and the Brazilian $2000 \mathrm{HDI}$ was $0.800^{(8)}$.

The Segundo Tempo Program is an action undertaken by the National Department of Educational Sport of the Ministry of Sports, which assists youngsters from deprived communities and exposed to social risks. Its activities are mainly directed to sports practice guided by Physical Education professionals and performed during the shift opposite to the school shift. The Program operates in nearly 1,300 cities distributed all over the Brazilian territory, assisting 800 thousand youngsters. In Montes Claros, the Program assists 2 thousand children and adolescents.

Students were selected for the study by invitation to all participants in the Program from the city of Montes Claros.
However, the following exclusion criteria were adopted: lack of parental or guardian approval; absence in Program activities on the day scheduled for data collection; physical condition that precluded taking anthropometric measurements on that occasion. Hence, the study included 1,968 youngsters (982 girls and 986 boys).

Subjects' chronological age was determined in years and months, based on the comparison between date of data collection and date of birth. However, for analysis purposes, three age groups were established: seven to ten years (171 girls and 237 boys); 11 to 14 years (554 girls and 520 boys); and 15 to 17 years (257 girls and 229 boys). Indicators corresponding to low body weight/thinness, overweight and obesity were determined based on the calculation of the body mass index (BMI), the ratio between body weight, in kilograms, and height, expressed in meters squared $\left(\mathrm{kg} / \mathrm{m}^{2}\right)$, according to the criteria proposed by the International Obesity Task Force $(\mathrm{IOFT})^{(9,10)}$. This criterion uses cut-off values associated with BMI for age and sex, estimated from curves for several population studies, including for the Brazilian population, and that are related to cut-offs for low body weight/thinness, overweight and obesity in adults (BMI $=18.5,25$ and $30 \mathrm{~kg} / \mathrm{m}^{2}$, respectively), which are risk markers for morbidity and mortality from non-communicable chronic disorders.

Body weight was determined using an anthropometric scale (Seca, model 879, Hamburg, Germany), with 10g accuracy, measured every ten weightings; height was determined using an aluminum stadiometer (Seca, model 870, Hamburg, Germany), with $1 \mathrm{~mm}$ scale, based on the procedures presented by the World Health Organization ${ }^{(11)}$. The evaluators' team comprised two Physical Education professionals highly experienced in taking anthropometric measurements. As for the quality of data, body weight and height measurements were replicated every ten subjects included in the definitive study sample. Technical errors of measurement ranged from 30 to $50 \mathrm{~g}$ for body weight measurements, and from 1 to $5 \mathrm{~cm}$ for height measurements.

Data were statistically analyzed using the Statistical Package for the Social Science (SPSS), version 20.0. Anthropometric data were initially compared with normal curves, applying the Kolmogorov-Smirnov distance test. Body weight, height and BMI measures had a normal frequency distribution. The selected sample was characterized using descriptive statistics (mean and standard deviation) and two-way analysis of variance with interaction, involving two classification criteria: sex and age. The Scheffe's multiple comparison test was applied to identify specific differences. The prevalence of low body weight/thinness, overweight and obesity was determined by 
frequencies and their respective $95 \%$ confidence intervals, according to the cut-offs used. The significance test for comparison of multiple proportions was applied to investigate possible differences in the prevalence between the study groups, through the non-parametric chi-square test.

\section{Results}

Table 1 shows information regarding height, body weight and BMI measures that characterized the study sample.
Height and body weight values were similar up to nearly 14 years of age. Afterwards, boys became heavier and taller than girls. As for BMI, values showed growing increase with progressing age; however, these values were similar in both genders.

Table 2 shows the prevalence of low body weight/thinness, overweight and obesity stratified by gender and age. Girls had a lower prevalence of low body weight/thinness $(p=0.028)$ and a significantly higher prevalence of overweight and obesity than boys $(p<0.001$ and $p<0.041)$. For all ages,

Table 1 - Mean values, standard deviation and "F" statistics corresponding to height, body weight and body mass index measures of children and adolescents involved in the study

\begin{tabular}{|c|c|c|c|c|c|c|}
\hline \multirow{2}{*}{$\begin{array}{c}\text { Age } \\
\text { (Years) }\end{array}$} & \multicolumn{2}{|c|}{ Height $(\mathrm{cm})$} & \multicolumn{2}{|c|}{ Body Weight (kg) } & \multicolumn{2}{|c|}{ BMI $\left(\mathrm{kg} / \mathrm{m}^{2}\right)$} \\
\hline & Girls & Boys & Girls & Boys & Girls & Boys \\
\hline 7 & $125.12 \pm 7.84$ & $124.26 \pm 7.71$ & $26.79 \pm 5.48$ & $26.00 \pm 6.34$ & $16.37 \pm 3.04$ & $16.36 \pm 3.44$ \\
\hline 8 & $131.97 \pm 7.77$ & $131.25 \pm 8.54$ & $29.52 \pm 6.48$ & $28.17 \pm 6.23$ & $16.98 \pm 2.80$ & $16.71 \pm 3.27$ \\
\hline 9 & $135.81 \pm 7.33$ & $135.18 \pm 6.23$ & $32.85 \pm 7.33$ & $30.82 \pm 7.17$ & $17.02 \pm 2.78$ & $17.08 \pm 3.34$ \\
\hline 10 & $139.35 \pm 8.20$ & $141.31 \pm 8.02$ & $34.39 \pm 7.69$ & $36.17 \pm 8.09$ & $17.85 \pm 3.30$ & $17.13 \pm 3.35$ \\
\hline 11 & $145.07 \pm 6.94$ & $145.39 \pm 8.77$ & $38.30 \pm 7.29$ & $39.47 \pm 9.23$ & $18.14 \pm 2.75$ & $17.50 \pm 3.34$ \\
\hline 12 & $152.23 \pm 6.71$ & $149.53 \pm 7.12$ & $43.31 \pm 8.21$ & $41.27 \pm 8.48$ & $18.41 \pm 2.52$ & $18.08 \pm 3.19$ \\
\hline 13 & $156.25 \pm 7.30$ & $154.74 \pm 8.34$ & $46.75 \pm 9.90$ & $45.21 \pm 8.74$ & $18.75 \pm 3.34$ & $18.51 \pm 3.89$ \\
\hline 14 & $160.79 \pm 6.06$ & $160.18 \pm 9.97$ & $50.40 \pm 8.46$ & $49.44 \pm 9.07$ & $19.11 \pm 2.98$ & $18.92 \pm 3.25$ \\
\hline 15 & $161.13 \pm 6.76$ & $168.41 \pm 8.42^{*}$ & $52.90 \pm 8.61$ & $57.06 \pm 8.91^{*}$ & $20.18 \pm 3.24$ & $19.21 \pm 3.52$ \\
\hline 16 & $162.08 \pm 7.60$ & $171.47 \pm 6.83^{* *}$ & $53.80 \pm 7.86$ & $58.92 \pm 8.56^{*}$ & $20.21 \pm 3.03$ & $21.32 \pm 2.71$ \\
\hline 17 & $162.36 \pm 6.83$ & $173.81 \pm 6.42^{* *}$ & $54.12 \pm 8.07$ & $60.15 \pm 9.62^{* *}$ & $20.34 \pm 3.12$ & $21.72 \pm 2.86$ \\
\hline $\mathrm{F}_{\text {age }}$ & \multicolumn{2}{|c|}{$p<0.001$} & \multicolumn{2}{|c|}{$p<0.001$} & \multicolumn{2}{|c|}{$p<0.001$} \\
\hline $\mathrm{F}_{\mathrm{sex}}$ & \multicolumn{2}{|c|}{$p<0.001$} & \multicolumn{2}{|c|}{$p<0.001$} & \multicolumn{2}{|c|}{$p=0.142$} \\
\hline$F_{\text {interaction }}$ & \multicolumn{2}{|c|}{$p<0.001$} & \multicolumn{2}{|c|}{$p<0.001$} & \multicolumn{2}{|c|}{$p=0.072$} \\
\hline
\end{tabular}

${ }^{*} 0.01<p<0.05 ;{ }^{* *} p<0.01$; BMI: body mass index; F: difference for main effect

Table 2 - Prevalence and 95\% confidence interval of low body weight/thinness, overweight and obesity according to sex and age group

\begin{tabular}{|c|c|c|c|c|c|c|}
\hline \multirow{2}{*}{$\begin{array}{l}\text { Age Group } \\
\text { (Years) }\end{array}$} & \multicolumn{2}{|c|}{ Low Weight/Thinness } & \multicolumn{2}{|c|}{ Overweight } & \multicolumn{2}{|c|}{ Obesity } \\
\hline & Girls & Boys & Girls & Boys & Girls & Boys \\
\hline \multirow[t]{2}{*}{$7-10$} & 2.7 & 3.2 & 24.7 & 18.6 & 5.4 & 4.8 \\
\hline & $(2.2-3.2)$ & $(2.7-3.7)$ & $(22.6-27.0)$ & $(17.0-20.3)$ & $(4.5-6.4)$ & $(4.0-5.7)$ \\
\hline \multirow[t]{2}{*}{$11-14$} & 3.8 & 5.9 & 17.2 & 12.8 & 3.6 & 2.5 \\
\hline & $(3.2-4.5)$ & $(5.2-6.7)$ & $(15.7-18.8)$ & $(11.9-14.0)$ & $(3.0-4.3)$ & $(2.1-3.0)$ \\
\hline \multirow[t]{2}{*}{$15-17$} & 5.5 & 9.4 & 13.9 & 8.1 & 2.3 & 1.1 \\
\hline & $(4.8-6.2)$ & $(8.6-10.3)$ & $(12.6-15.3)$ & $(7.3-8.9)$ & $(1.9-2.7)$ & $(0.8-1.5)$ \\
\hline \multirow[t]{2}{*}{$7-17$} & 4.1 & 6.3 & 18.4 & 13.2 & 3.8 & 2.9 \\
\hline & $(3.5-4.7)$ & $(5.6-7.1)$ & $(16.9-20.0)$ & $(12.1-14.3)$ & $(3.3-4.3)$ & $(2.4-3.4)$ \\
\hline$\chi^{2} \operatorname{sex}$ & \multicolumn{2}{|c|}{$p=0.028$} & \multicolumn{2}{|c|}{$p<0.001$} & \multicolumn{2}{|c|}{$p=0.041$} \\
\hline$\chi_{\text {Age Group }}^{2}$ & \multicolumn{2}{|c|}{$p<0.001$} & \multicolumn{2}{|c|}{$p<0.001$} & \multicolumn{2}{|c|}{$p=0.001$} \\
\hline
\end{tabular}


$4.1 \%$ of girls and $6.3 \%$ of boys had low body weight/thinness. As for excess body weight, $18.4 \%$ of girls and $13.2 \%$ of boys were overweight, along with 3.8 and $2.9 \%$, respectively, who were obese.

As for age groups, a significant increase in the prevalence of low body weight/thinness was observed with age in both genders $(p<0.001)$. In this case, the prevalence of low body weight/thinness among adolescents of both genders included in the 15-17 year age group were approximately two to three times higher $(5.5 \%$ of girls and $9.4 \%$ of boys) compared to their counterparts included in the age group from seven to ten years (2.7 and 3.2\%, respectively). On the other hand, as for the prevalence of overweight and obesity, estimates indicated significant lower proportions with advancing age $(p<0.001$ and $p=0.001$ ). In the younger group (from seven to ten years), overweight prevalence was $24.7 \%$ among girls and $18.6 \%$ among boys; in the adolescent group (from 15 to 17 years), these percentages were 13.9 and $8.1 \%$, respectively. Similarly, although in smaller proportions, prevalence of obesity among the youngest subjects was close to $5 \%$ in both genders. However, for more advanced ages, it was found that boys showed a more significant reduction, with obesity reaching $2.3 \%$ of girls and $1.1 \%$ of boys in the $15-17$ year age group.

\section{Discussion}

Based on values corresponding to BMI, the prevalence of low body weight/thinness, overweight and obesity was estimated in a representative sample of children and adolescents assisted by the Segundo Tempo Program of the Ministry of Sports. The results revealed that, using sex- and age-specific cut-offs recently proposed by the $\operatorname{IOFT}^{(9,10)}$, the estimate of the combined prevalence of excess body weight (overweight and obesity) in the study sample (19.2\%) was nearly four times higher than the prevalence of low body weight/thinness $(5.2 \%)$.

In this sense, the lack of unanimity in the definition of cutoff points to identify low body weight/thinness, overweight and obesity at younger ages acts as the main barrier to perform comparative analyses of the different studies available in the literature. However, compared to international data, which also used cut-offs proposed by the IOFT, the prevalence of low body weight/thinness observed in the present study was lower than that described in the young population of African ${ }^{(12,13)}$ and Asian ${ }^{(14,15)}$ countries but similar to the prevalence observed in European countries ${ }^{(16,17)}$. With regard to the prevalence of overweight and obesity, the percentages we have found were higher than those observed in the young population of African ${ }^{(18,19)}$ and Asian ${ }^{(20,21)}$ countries and were close to the values described in the youth population of North American and European ${ }^{(22)}$ countries.

As for the comparison with results previously observed in Brazilian studies, few methodological designs involving combined representative samples of children and adolescents from the population segment being considered assessed the prevalence of low body weight/thinness, overweight and obesity using the cut-offs suggested by the IOFT. Because of the few studies susceptible to comparison, it was found that the population segment being analyzed had higher prevalence of low body weight/thinness compared to the survey conducted in Niterói, state of Rio de Janeiro, Brazil $(2.7 \text { versus } 5.2 \%)^{(23)}$. As for the combined prevalence of overweight and obesity, the frequency found in the present study (19.2\%) was close to the values reported in studies conducted in the Brazilian cities of Rio de Janeiro, state of Rio de Janeiro (18\%) $)^{(24)}$, Pelotas, state of Rio Grande do Sul $(20 \%)^{(25)}$, and Florianópolis, state of Santa Catarina $(21 \%)^{(26)}$. However, in comparison to investigations involving the young population of capital cities of Northeastern Brazil, the combined prevalence of overweight and obesity reported here was higher than that found in João Pessoa, state of Paraíba $(10.5 \%)^{(27)}$, and in Recife, state of Pernambuco $(13.9 \%)^{(28)}$.

The prevalence of low body weight/thinness, overweight and obesity was not equally distributed in the population segment analyzed in the present study. As for gender, if, on one hand, the prevalence of low body weight/thinness was significantly higher in boys, on the other hand, girls showed higher percentages when it comes to the prevalence of overweight and obesity. In other studies available in the literature, significant differences were also observed in the prevalence of low body weight/thinness ${ }^{(12,14)}$ and overweight/obesity ${ }^{(18-22)}$ in both genders.

The differences observed in the prevalence of low body weight/thinness between boys and girls may possibly be explained by sexual specificities related to biological sensitivity to environmental aggressions, mainly those of nutritional nature. Although the justifications and the mechanisms of this phenomenon are not well defined, Stinson ${ }^{(29)}$ suggests that the male organism would be more sensitive to negative environmental influences. In this case, boys under stressful environmental conditions showed higher risk associated with prenatal mortality, retarded physical growth and the onset and development of infectious diseases, when compared to girls. 
On the other hand, it is suspected that the higher prevalence of overweight and obesity in girls may be partly explained by the greater susceptibility of the female organism to store greater body fat deposits, which occurs due to sexual hormones at ages close to puberty ${ }^{(30)}$. Differences regarding physical activity habits may also contribute to the variations in the prevalence of overweight and obesity between genders. At school age, boys showed to be consistently more physically active than girls, both in daily activities and in systematic programs of physical exercise and sports, differences that become more pronounced during adolescence ${ }^{(31)}$.

The increase in the prevalence of low birth weight/thinness with progressing age found here may be possibly related to the epidemiological transition that has been more recently observed in developing Brazilian regions. Specifically in Northern Minas Gerais state, where the target population of the present study lives, social and infrastructure advances in public services, mainly in the education and health sectors, associated with assistance and income transfer programs, may contribute to the improved weight profile of younger individuals compared to their older counterparts, considering that, a decade ago, period when current adolescents were children, there were almost no such initiatives, which has a strong impact on the definition of their future body weight. This phenomenon was similarly observed in the young population of other Brazilian regions ${ }^{(32,33)}$ and in African countries ${ }^{(34)}$, significantly changing the trend in the prevalence of low birth weight/thinness.

Thus, low body weight/thinness, which was an important concern in past decades in the Brazilian pediatric population ${ }^{(35)}$, seems to be a nutritional issue that is about to be overcome in the population segment being analyzed, since, according to the statistical criteria adopted for the epidemiological classification of nutritional deficit, a prevalence of up to $2.5 \%$ is acceptable in populations with good nutritional status ${ }^{(11)}$. At the ages from seven to ten years, the prevalence of body weight deficit/ thinness in the present study was 2.7 and $3.2 \%$ in girls and boys, respectively, being thus very similar to the acceptable percentage. However, while there are indications of a possible control of the occurrence of low body weight/thinness, it was found that the presence of excess body weight reached alarming proportions, since one out of five youngsters analyzed in the study were overweight or obese (19.2\%), pointing out the need for urgent prevention and control actions.

Among the main limitations of the study, one of the most important is the procedure used to select the sample. Because it was a specific population group, i.e., participants in the Segundo Tempo Program, there are restrictions when to comes to generalizing the results for the entire young population. However, given the reach of the Program throughout the country and the greater size of the selected sample, the results we have found probably depict satisfactorily the prevalence of low body weight/thinness, overweight and obesity and its distribution according to sex and age in the young population of Montes Claros. Similarly, the cross-sectional design of the study prevents the establishment of causal effects on the outcomes related to body weight and advancing age.

Thus, the information obtained in the study points out that, although it is a population segment integrated in a region of low economic development and with low social indicators, excess body weight was the main problem associated with nutritional status. The high prevalence of overweight and obesity reported here warns about the urgent need of public policies for health promotion, especially those directed to healthy eating habits and physical activity.

Considering that both low body weight/thinness and overweight and obesity are conditions with severe short and long-term health repercussions, with regard to the prevalence found in both nutritional indicators, it is worth emphasizing the importance of maintaining actions to control starvation and malnutrition in the population. However, it is necessary to adjust the guidelines of currents actions and to clearly define the profile of their beneficiaries concerning the greater accumulation of body fat, due to the possible effects of foods with high calories and low nutritional value, associated with low levels of physical activity. In this case, it is suggested that the access of the population to food should be accompanied by a specific education process focused on adequate consumption, nutritional needs and the regular practice of physical effort specific to increase energy expenditure.

\section{References}

1. Popkin BM. Urbanization, lifestyle changes and the nutrition transition. World Dev 1999;27:1905-16.

2. Best C, Neufingerl N, van Geel L, van den Briel T, Osendarp S. The nutritional status of school-aged children: why should we care? Food Nutr Bull 2010;31:400-17.

3. Flegal KM, Graubard BI, Williamson DF, Gail MH. Excess deaths associated with underweight, overweight, and obesity. JAMA 2005;293:1861-7.

4. Park MH, Falconer C, Viner RM, Kinra S. The impact of childhood obesity on morbidity and mortality in adulthood: a systematic review. Obes Rev 2012;13:985-1000. 
5. Kiess W, Galler A, Reich A, Müller G, Kapellen T, Deutscher J et al. Clinical aspects of obesity in childhood and adolescence. Obes Rev 2001;2:29-36.

6. Brasil - Instituto Brasileiro de Geografia e Estatística [homepage on the Internet]. Estudo Nacional de Despesa Familiar. Dados preliminares. Consumo alimentar Antropometria. Rio de Janeiro: IBGE; 1977 [cited 2013 Jun 20]. Available from: http://biblioteca.ibge.gov.br/visualizacao/monografias/GEBIS\%20-\%20RJ/ ConsumoAlimentar/v1\%20t1\%20-\%20Parte\%204\%20-\%20DF,\%20RO,\%20 AC,\%20AM,\%20RR,\%20PA,\%20AM,\%20GO\%20e\%20MT.pdf

7. Brasil - Instituto Brasileiro de Geografia e Estatística. Pesquisa de orçamentos familiares 2008-2009: antropometria e estado nutricional de crianças, adolescentes e adultos no Brasil. Rio de Janeiro: IBGE; 2010.

8. Programa das Nações Unidas para o Desenvolvimento [homepage on the Internet]. Atlas de Desenvolvimento Humano 2003. Ranking do IDH dos Municípios do Brasil 2003. Brasília: PNUD; 2003 [cited 2013 Jul 10]. Available from: http://www.pnud.org.br/atlas/ranking/IDH_Municipios_Brasil_2000. aspx?indiceAccordion=1\&li=li_Ranking2003

9. Cole TJ, Bellizzi MC, Flegal KM, Dietz WH. Establishing a standard definition for child overweight and obesity worldwide: international survey. BMJ 2000;320:1240-3.

10. Cole TJ, Flegal KM, Nicholls D, Jackson AA. Body mass index cut-offs to define thinness in children and adolescents: international survey. BMJ 2007;335:194-7.

11. World Health Organization. Physical status: the use and interpretation of anthropometry. Report of a WHO Expert Committee. [Technical Report Series no 854]. Geneva: WHO; 1995.

12. Bovet $\mathrm{P}$, Kizirian N, Madeleine G, Blössner M, Chiolero A. Prevalence of thinness in children and adolescents in the Seychelles: comparison of two international growth references. Nutr J 2011;10:65.

13. Caleyachetty R, Rudnicka AR, Echouffo-Tcheugui JB, Siegel KR, Richards N, Whincup PH. Prevalence of overweight, obesity and thinness in 9-10 year old children in Mauritius. Global Health 2012;8:28.

14. Kelishadi R, Ardalan G, Gheiratmand R, Majdzadeh R, Hosseini M, Gouya MM et al. Thinness, overweight and obesity in a national sample of Iranian children and adolescents: CASPIAN Study. Child Care Health Dev 2008;34:44-54.

15. Bisai S, Ghosh T, Kumar De G, Bose K. Very high prevalence of thinness among Kora-Mudi tribal children of Paschim Medinipur district of West Bengal, India. EJBS 2010;3:43-9.

16. Lazzeri G, Rossi S, Pammolli A, Pilato V, Pozzi T, Giacchi MV. Underweight and overweight among children and adolescents in Tuscany (Italy). Prevalence and short-term trends. Prevalence and short-term trends. J Prev Med Hyg 2008;49:13-21.

17. Marques-Vidal P, Ferreira R, Oliveira JM, Paccaud F. Is thinness more prevalent than obesity in Portuguese adolescents? Clin Nutr 2008;27:531-6.

18. Ben-Bassey UP, Oduwole AO, Ogundipe OO. Prevalence of overweight and obesity in Eti-Osa LGA, Lagos, Nigeria. Obes Rev 2007;8:475-9.

19. Armstrong ME, Lambert MI, Sharwood KA, Lambert EV. Obesity and overweight in South African primary school children - The Health of the Nation Study. S Afr Med J 2006;96:439-44.

20. Laxmaiah A, Nagalla B, Vijayaraghavan K, Nair M. Factors affecting prevalence of overweight among 12- to 17-year-old urban adolescents in Hyderabad-India. Obesity (Silver Spring) 2007;15:1384-90.
21. Xie B, Chou CP, Spruijt-Metz D, Reynolds K, Clark F, Palmer PH et al. Socio-demographic and economic correlates of overweight status in Chinese adolescents. Am J Health Behav 2007;31:339-52.

22. Janssen I, Katzmarzyk PT, Boyce WF, Vereecken C, Mulvihill C, Roberts C et al. Comparison of overweight and obesity prevalence in school-aged youth from 34 countries and their relationships with physical activity and dietary patterns. Obes Rev 2005;6:123-32.

23. Gomes Fda S, Anjos LA, Vasconcellos MT. Influence of different body mass index cut-off values in assessing the nutritional status of adolescents in a household survey. Cad Saude Publica 2009;25:1850-7.

24. Anjos LA, Castro IR, Engstrom EM, Azevedo AM. Growth and nutritional status in a probabilistic sample of schoolchildren from Rio de Janeiro, 1999. Cad Saude Publica 2003;19 (Suppl 1):S171-9.

25. Vieira MF, Araújo CL, Neutzling MB, Hallal PC, Menezes AM. Diagnosis of overweight and obesity in adolescentes from the 1993 Pelotas birth cohort study, Rio Grande do Sul state, Brazil: comparison of two diagnostic criteria. Cad Saude Publica 2007;23:2993-9.

26. Bernardo Cde O, Vasconcelos Fde A. Association of parents' nutritional status, and sociodemographic and dietary factors with overweight/obesity in schoolchildren 7 to 14 years old. Cad Saude Publica 2012;28:291-304.

27. Farias Júnior JC, Silva KS. Overweight/obesity in adolescente students from the city of João Pessoa, PB, Brazil: prevalence and association with demographic and socioeconomic factors. Rev Bras Med Esporte 2008;14:104-8.

28. Tassitano RM, Barros MV, Tenório MC, Bezerra J, Hallal PC. Prevalence of overweight and obesity and associated factors among public high school students in Pernambuco state, Brazil. Cad Saude Publica 2009; 25:2639-52.

29. Stinson S. Sex differences in environmental sensitivity during growth and development. Am J Phys Anthrop 1985;28:123-47.

30. Malina RM, Bouchard C, Bar-Or O. Growth, maturation, and physical activity. $2^{\text {nd }}$ ed. Champaign: Human Kinetics; 2004.

31. Ferreira I, van der Horst K, Wendel-Vos W, Kremers S, van Lenthe FJ, Brug J. Environmental correlates of physical activity in youth: a review and update. Obes Rev 2006;8:129-54

32. Guedes DP, de Matos JA, Lopes VP, Ferreirinha JE, Silva AJ. Physical growth of schoolchildren from the Jequitinhonha Valley, Minas Gerais, Brazil: comparison with the CDC-2000 reference using the LMS method. Ann Hum Biol 2010;37:574-84.

33. Guedes DP, Rocha GD, Silva AJ, Carvalhal IM, Coelho EM. Effects of social and environmental determinants on overweight and obesity among Brazilian schoolchildren from a developing region. Rev Panam Salud Publica 2011;30:295-302.

34. Prista A, Maia JA, Damasceno A, Beunen G. Anthropometric indicators of nutritional status: implications for fitness, activity, and health in schoolage children and adolescents from Maputo, Mozambique. Am J Clin Nutr 2003;77:952-9.

35. Monteiro CA, Benicio MH, lunes R, Gouveia NC, Taddei JA, Cardoso MA. ENDF and PNSN: trends in physical growth of Brazilian children. Cad Saude Publica 1993;9 (Suppl 1):585-95. 